\title{
Tekst i przed-tekst. Bruliony wiersza Oskara Miłosza
}

(fragmenty)*

Jean Bellemin-Noël

\begin{abstract}
*Przekład wykonany na podstawie wydania francuskiego: Jean Bellemin-Noël, Le texte et l'avant-texte: les brouillons d'un poème de Milosz (Paris: Librairie Larousse, 1971). Wszystkie przypisy - jeśli nie zaznaczono inaczej - pochodzą od tłumacza.
\end{abstract}

\section{Od tłumacza. Krytyka genetyczna - specyfika przekładu}

Prezentowane tu fragmenty przekładu pracy Jeana Bellemin-Noëla, poświęconej brulionom Oskara Miłosza, sporządzone zostały pierwotnie jako metodologiczny punkt odniesienia dla grupy polskich badaczy, chcących zaadaptować proponowane w niej rozwiązania na grunt rodzimy. W istocie, nie zamówiono przekładu, tylko „wykładnię metodologii”. Być może w takim ujęciu zadanie dałoby się zrealizować $\mathrm{w}$ formie podpartego precyzyjnymi notatkami seminarium, tłumacz jednak zdecydował się tłumaczyć. Trudno dziś orzec uczciwie, czy uległ tym samym sile nawyku, kompulsywnemu perfekcjonizmowi, pokusie ambitnego wyzwania - czy też po prostu nie zrozumiał wszystkiego, czego odeń oczekiwano. Dość powiedzieć, że przyjęty modus operandi, który sam tłumacz chciałby uznać za „profesjonalny”, ściągnął nań nie lada kłopoty.

Nie chodzi tylko o doniosłość tekstu Bellemin-Noëla, który na początku lat 70. ubiegłego wieku stwarza podwaliny metodologiczne perspektywy badawczej zwanej "genetyką literacką". Nie chodzi nawet o oryginalny styl tego badacza, który nieraz sam bywa poetą, gdy na przykład, mówiąc o powstawaniu wiersza, odrzuca biologiczne metafory zalążków i pędów, by zwrócić się ku krystalografii. Może zresztą są to fragmenty, w których jest Bellemin-Noël najbardziej przejrzysty i pociągający. W tych zapamiętałych okresach eseistycznej refleksji, w skojarzeniach raz mistycznych, raz psychoanalitycznych, wreszcie w grach słów, gdy zdaje się nie liczyć z udręką przyszłego tłumacza, najprecyzyjniej i najjaśniej pochwytuje subtelną naturę rzemiosła, którego tajnie podejmuje się przecież badać metodami najzupełniej empirycznymi. 
Wszystkie te zawiłości, metafory, analogie, kalambury napotkać można wszelako w pracach licznych humanistów, a i fizycy nie są od nich wolni. Tym, co czyni krytykę genetyczną przypadkiem wyjątkowym z punktu widzenia tłumacza, jest sam przedmiot jej studium: nie tekst, ale przed-tekst. Przed-tekstem jest wszystko to, co w zachowanych źródłach pisanych poprzedza ostateczną wersję dzieła, którą autor odda do druku. Wynika z powyższego, że przed-tekst nie jest samym dziełem, nie jest nawet tekstem jako takim, jest natomiast jego tworzywem, materią, z której tekst się ukształtuje. Tym samym przed-tekst zawiera w sobie nie tylko sam tekst - i niekoniecznie w identycznym kształcie - lecz także te jego elementy, które w procesie redakcji autor z różnych przyczyn odrzucił albo też, by ująć rzecz w dramatycznych ramach innej zgoła szkoły, wyparł.

Oznacza to w praktyce wiele trudności, które uczciwość nakazuje choćby pokrótce omówić. Przede wszystkim niezależnie od gatunku literackiego, niezależnie od zdolności danego twórcy, trzeba obiektywnie skonstatować, iż przedmiotem studium krytyki genetycznej są, jak by nie patrzeć, próbki, skreślenia, poprawki, jeśli nie nawet odpady, bełkoty, bazgroły. Są to zresztą w większości ściśle zdefiniowane terminy, jakimi posługuje się sam Bellemin-Noël. Jeżeli więc badacz oddaje się skrupulatnej klasyfikacji, analizie i opisowi powyższych elementów, przywołując je w formie dokładnych cytatów, tłumacz zmuszony jest zrekonstruować w języku docelowym nie tyle ich "niespełnione”, „niewydarzone”, „odrzucone” znaczenie, ile samo ich niespełnienie, niewydarzenie, odrzucenie. Mowa bowiem o znaczeniu w chwili, gdy pozostaje ono w stadium swego konstruowania, na etapie stawania się. $\mathrm{W}$ tym sensie obcowanie $\mathrm{z}$ przed-tekstem jest może formą voyeuryzmu, kiedy to badacz przyłapuje poetę w chwili, gdy ten głośno myśli. Przed-tekst jest więc dokumentem procesu wypowiadania, poszukiwania sensu i jego werbalizacji, a także organizacji wypowiedzi literackiej w czasie i przestrzeni. Nie oznacza to skądinąd, że nie można w ogóle mówić o znaczeniu w wypadku przed-tekstu, podobnie, jak nie jest konieczne - i niekoniecznie możliwe - mówienie o jedynym znaczeniu w wypadku tekstu ukończonego. Nie ulega jednak wątpliwości, że to proces, nie zaś jego owoc, stanowi główny przedmiot zainteresowania genetyki literackiej.

Ślady tego procesu, jakkolwiek często nieczytelne, niespełnione, nieraz bełkotliwe, tłumacz zmuszony jest przybliżyć rodzimemu czytelnikowi. Tam, gdzie celem byłoby oddanie czytelnikowi tekstu ostatecznego, który zyskał społeczne miano „dzieła” jako wydany i oddany publice, tłumacz mógłby podjąć się samodzielnego przekładu lub wykorzystać przekład już istniejący (w tym wypadku autorstwa Czesława Miłosza). Gdzie jednak w grę wchodzą kolejne wersje, zarzucone warianty, martwe odnogi tekstu, dopiski, wtrącenia, przeniesienia całych fragmentów z jednej strofy do drugiej, zamiany całych słów lub tylko gramatyczne ich derywacje - słowem: literacki byt potencjalny - tam tłumacz zdany jest w głównej mierze na intuicję. Co więcej, jak się zdaje, zapomnieć musi o szacunku dla formy i dobrym smaku - wartościach, które winny przyświecać tłumaczeniu wszelkiej literatury. Toteż przywoływane przez autora fragmenty przed-tekstu podajemy z reguły w oryginale, proponując w przypisach ich doraźne, użytkowe tłumaczenia, niepretendujące do miana „literackiego przekładu”. Nie mogło być inaczej: próba pominięcia oryginalnych fragmentów przed-tekstu i zastąpienia ich choćby tylko orientacyjnymi przekładami, szczególnie w wypadku wiersza, pozbawiłaby czytelności całe skrupulatne studium, jakiego dokonuje Bellemin-Noël. Tym bardziej nie mogłoby być mowy o wprowadzeniu propozycji przekładu artystycznego, implikującego z natury swej manipulacje tak dalekie, iż - jeśli nawet, jakimś trafem - przekład „próbek” i „wariantów” wiersza zyskałby wartość literacką, a treść refleksji Bellemin-Noëla stałaby się nieczytelna. W studium 
genetycznym nie liczy się przecież jedynie końcowy efekt estetyczny, lecz proces jego produkcji, poszukiwania go. Dlatego też nieraz, przyznać to trzeba, przekład fragmentów przed-tekstu oscyluje między groteską a zwyczajną niezgrabnością. Tłumaczenie ich jest bowiem ze strony tłumaczącego próbą naśladowania swoistego „stylu kognitywnego” autora, jego ekstatycznych uniesień i analitycznych powściągnięć - a także jego omyłek, zawahań, mitygowań.

Usprawiedliwiwszy tym samym, w miarę możliwości, wymuszoną niezgrabność przekładów poezji Oskara Miłosza pochwyconej w procesie jej krystalizacji, oddajemy w ręce Czytelników fragmenty jej opracowań w perspektywie genetycznej proponowanej przez Jeana Bellemin-Noëla. Winny one w naszym przekonaniu przybliżyć zainteresowanym założenia, cele, definicje operacyjne oraz niektóre konkluzje francuskiego badacza, innymi słowy: dostarczyć metodologicznej inspiracji oraz ściśle zdefiniowanych punktów odniesienia, mogących służyć rozwojowi badań genetycznych na gruncie literaturoznawstwa polskiego.

Karol Krzyżosiak

\section{Projekt pracy}

Korpus, z którym mamy do czynienia, ma wszystkie cechy prawdziwie cennej schedy literackiej. Jest to rzadka sposobność: od pierwszej linijki (pierwotnej mgławicy, czy może zalążka - to teraz nieistotne) aż po końcowy rękopis, możemy prześledzić proces redakcji utworu. Ponad trzy czwarte brulionów Oskara Miłosza znajduje się w zeszycie, którego strony są ponumerowane, jak gdyby sam pisarz, świadomie zostawiając za sobą nić, wyznaczył potomnym drogę do zrozumienia swego aktu twórczego. Jakże oprzeć się takiej zachęcie?

Podejmiemy się tego, postępując początkowo metodą najbardziej klasyczną; z bardzo prostego powodu: Oskar Miłosz pozostaje poetą mało znanym, jego wiersz La Charrette jest czytelnikom niemal zupełnie nieznany - nie ma tu nic z tego, co zwykle rozbrzmiewa w uczonych rozprawach. Nie może być mowy o przekazaniu w ręce czytelników brulionu bez uprzedniego przedstawienia stanu końcowego, wobec którego brulion zyskuje status przed-tekstu i względem którego odczytania będą nabierały sensu. Prócz tego ukazana zostanie pokrótce perspektywa okoliczności powstawania tekstu: nie dlatego, powiedzmy to raz jeszcze, żebyśmy interesowali się bełkotem i bazgraniną jakiegoś autora, lecz dlatego, że pisarz okazuje się pierwszym czytelnikiem swego dzieła (nawet jeśli nie jest czytelnikiem uprzywilejowanym); właśnie wskutek jego sukcesywnych odczytań przyszłego przed-tekstu zaczyna istnieć tekst. Każde wznowienie pisania, każde przekształcenie, każde zatrzymanie pracy lub dodanie czegoś - ma znaczenie pierwszego odczytania. Można stwierdzić, że pisanie jest zawsze aktem wtórnym wobec czytania, jest projekcją na papier zapisu „mentalnego”, który piszący odczytuje w swej głowie i który następnie kopiuje mniej lub bardziej wiernie; możemy sobie wyobrazić, że sposób redakcji każdego pisarza różni się zależnie od „mentalnych” przekreśleń, których dokonuje (na przykład w pamięci), zanim jego ręka nakreśli na papierze ostateczne znaki.

To ze względu na wybór metodologiczny pragniemy zminimalizować rolę pisarza (jako osoby) w toku tego eksperymentalnego studium. Jednakże wydaje się niedorzecznością nie skorzy- 
stać z okazji do ustalenia pewnych relacji pomiędzy Miłoszem a dokumentem, jaki stanowią jego bruliony. Oprócz wzięcia pod uwagę obecności autora, projektując w pewien sposób jego spojrzenie na powstający tekst, sporządzimy także pobieżną panoramę „otoczenia” jego wiersza: w czym wiersz ten przypomina inne utwory poety, jakie niewykorzystane pozostałości zawarł poeta w swych pismach późniejszych. Profil leksykologicznego dzieła oraz eksploracja uniwersum wyobrażeniowego zostaną umieszczone w Dodatku, ponieważ nie należą ściśle do terytorium określonego jako pole badania. La Charrette jest wierszem centralnym, ze względu zarówno na chronologię, jak i na wydźwięk jest tekstem znamiennym.

Jeśli chodzi o same bruliony, ich materialne przedstawienie ujawniło liczne problemy. Czy należało odtworzyć je in extenso? Bez wątpienia należało: Miłosz, jeśli możemy pozwolić sobie na takie stwierdzenie, zdaje się w trakcie redagowania pisać dużo i myśleć niewiele. Nie roztrząsa danego sformułowania przed jego zapisaniem, jego ręka, jak się zdaje, stara się konkurować w wyścigu z prędkością operacji mentalnych. Miłosz brał z sobą swój maleńki zeszyt i - stroniąc od pulpitów i kałamarzy - używał ołówka, ten zaś nigdy nie robi kleksów i nie wysycha. Można by uznać, że wszelkie wahania poety uległy materializacji, żadna idea nie została utracona. Stąd też wszystko ma znaczenie i zasługuje na wzięcie pod uwagę. Lecz skoro odrzuciliśmy zastosowanie faksymile, jakże zrekonstruować typograficznie strony tak całkowicie zapełnione? Czy raz jeszcze narzucić nieprzygotowanemu czytelnikowi odszyfrowywanie siedemdziesięciu pięciu kart i żmudne przeżuwanie kolejnych wznowień? Zrezygnowaliśmy z tego, poszukując rozwiązania bardziej stosownego. Zdecydowaliśmy się zatem na system przecięć: użyliśmy obszernych fragmentów rękopisu, korzystając z pewnych „bilansów” (zaczątków lub szkiców), które sam pisarz wyodrębniał, a następnie kopiował własnoręcznie, nim posunął się dalej. Kilka detali, jak mawiają fotografowie sztuki, zaproponowanych zostanie w rozszerzeniu, czy to w trakcie ogólnej prezentacji, czy też przy okazji badania pod mikroskopem. Nie możemy jednak ulec złudzeniu: to, co w tych warunkach jawi się jako reprodukcja, jest już, wskutek dokonanego okrojenia, interpretacją. Wkroczenie (drugiego) uprzywilejowanego czytelnika pomiędzy Miłosza oraz wersję opublikowaną było bez wątpienia mniejszym złem. Przynajmniej nie falsyfikuje ono tekstu w celu wykazania rzeczy z góry założonych.

Podobne złudzenie absolutnej obiektywności odrzucić należy w odniesieniu do opisu pracy przed-tekstu. Nie sposób zaprezentować nieustannych transformacji dokonywanych w toku i za sprawą praktyki, którą nazywamy redakcją: dla każdego zmienionego wyrazu należałoby wyprowadzić obszerny kontekst ( $w$ tekście), aby zmierzyć wstrząs, jaki zmiana ta wywołała na poziomie sensu. Pociągałoby to za sobą wprowadzanie nieskończonej liczby komentarzy za każdym razem, przy każdej modyfikacji... Miast śledzić tekst krok po kroku, określiliśmy poziomy analizy, następnie zaś wybraliśmy, na różnych poziomach, kilka znamiennych próbek. Znaleźliśmy i uwypukliliśmy pewne momenty, w których wyraz lub całe zdanie jednocześnie powoduje lokalną metamorfozę i jej ulega. Nie czynimy przy tym systematycznego rozróżnienia pomiędzy osiami transformacji (paradygmatyczną oraz syntagmatyczną); musieliśmy tym samym zrezygnować ze wskazywania za każdym razem reperkusji tych przemian. Jeśli nawet prześledziliśmy okazjonalnie rozwój linii melodycznej, zdajemy sobie sprawę, że nie mogliśmy w ten sposób odtworzyć całej symfonii: harmonia „mikrostruktur” przenika zaledwie kilka przecięć.

Pomimo takiej techniki badania można było wysunąć i obronić pewne hipotezy dotyczące tego, co nazwiemy fermentacją lub krystalizacją motywów. Stale też staraliśmy się nie tracić z oczu dwóch 
równoległych procesów, to znaczy: badania przemieszczeń pisania oraz wyłaniania się pewnego znaczenia - aktu pisania i struktury tekstu. Wszelako w ostatniej fazie analizy rozdźwięk ten okaże się wyraźnie złagodzony. Rozważymy sposób, w jaki przed-tekst, implicite, pozwala ponownie odczytywać dzieło, to znaczy czytać tekst. Ujrzymy, jak uporządkowanie wszystkiego, co poddane zostało transformacji, szczególnie zaś systemu usunięć, wyznacza nowe odczytania, dzięki którym to, co wykluczone, stłumione, wyparte, otrzymuje status znaku, nadając zarazem sens temu, co je wypiera lub zastępuje (choćby miała to być nieobecność). Tekst objawi się jako przestrzeń podziurawiona, dyskurs zamieszkany przez przemilczenia, w którym to, co negatywne (zaprzeczone, odwołane, nieprzyznane), okazuje się zdumiewająco aktywne.

Tak oto wyłania się kwestia brulionu, co do której nie możemy się zwodzić w nieskończoność: dlaczego ta praktyka, którą jest przed-tekst, przerwana została $w$ tym miejscu, zgodnie z linią podziału, która zwie się odtąd tekstem? Jak, w odniesieniu do czego lub do kogo, mocą jakiej władzy, jakiej instancji, ustalone zostało przecięcie Tautologią jest ogłoszenie wiersza ukończonym, gdy jest doskonały, co sprowadza się do uznania go za zwieńczony, gdy jest zwieńczony, lub też piękny, gdy zdaje się piękny. Można wyobrazić sobie, iż fabrykacja opiera się na dynamizmie stopniowo nasycającej się struktury, iż forma jest uformowana, kiedy w jej sferze nie ma już czego formować. Akceptujemy ideę, zgodnie z którą nieświadome ma coś do powiedzenia i ucieka się ostatecznie do wyznaczenia klauzury tekstu przez punkt dokładnej równowagi, gdzie to, co ma być ujawnione i ukryte, zarazem odsłania się i pozostaje zawinięte w swych fałdach... Kiedy jednak słyszymy lub kiedy słyszymy ponownie - sygnał oznajmujący moment zwieńczenia pisania ${ }^{1}$ ?

Ostatni wreszcie problem, ale nie najmniejszy: czy wolność lektury ulega skrępowaniu, kiedy tekstowi towarzyszy przed-tekst? Jeżeli dowolne podejście jawi się zasadne, kiedy seria znaczących oferuje nam nić przewodnią, co dzieje się w wypadku, gdy nic w gąszczu niedokonanego nie pozwalała przewidzieć takiego rozwoju? Czy przed-tekst może orientować lektury pozytywnie i negatywnie? Oznaczyliśmy to już jako pierwszą lekturę, w pewien sposób antycypującą; antycypacja i retrospekcja sytuują się zawsze jedna w sercu drugiej: gdzie zatem byłby przywilej? W istocie, czytanie może być sposobem ponownego pisania brulionu - brulionu analogicznego (i) nieustannie odnawianego, oscylującego zawsze pomiędzy Tym Samym i Innym.

\section{$[\ldots]$}

\section{Propozycje terminologiczne}

\section{Definicje i pojęcia umowne}

Skreślenie - linia anulująca segment tekstu.

Brulion(y) - ogół pism redagowanych „z myślą o” publikowanym utworze i doń prowadzących; jego formą ukończoną jest manuskrypt. Wyrażenie „z myślą o” zawdzięcza cudzysłów temu, iż nabiera sensu jedynie retrospektywnie: w każdym momencie redakcji z perspektywy

\footnotetext{
${ }^{1}$ Byłożby impertynencją (i rzeczą niewłaściwą) uwzględnić przypadek, w którym to pisarz jest nasycony? Nie będąc usatysfakcjonowanym swym dziełem, może po prostu „mieć już dość” swojej pracy - przyp. aut.
} 
redagującego istnieje już utwór, nie zaś przygotowanie do niego. W stosunku do dzieła opublikowanego bruliony istnieją jako pozostałości.

Poprawka - skreślenie lub usunięcie, zastępujące zapisany fragment niezgodny z gramatyką ujętą w sensie bardzo szerokim: poprawności ortograficznej i syntaktycznej, lecz także sprostowania wypowiedzi niezrozumiałej (na przykład w wyniku przerwy w redakcji lub na skutek miejscowych przekształceń). Poprawka nie zmienia sensu.

Zaczątek - część lub całość brulionu, którą następujący po niej etap przekształca, anuluje lub uzupełnia; wszelako zaczątek, w przeciwieństwie do szkicu, nie może być odczytywany jako utwór ukończony.

Pismo - wszystko, co nadaje się do odczytania bez zewnętrznych oznaczeń.

Próbki - szczególny przypadek utworu, który autor, po opublikowaniu go, traktuje nie jako ukończony utwór, lecz jako (nowy) brulion.

Szkic - w przeciwieństwie do zaczątku, a także przez analogię z tym, co zaobserwować można w malarstwie, część brulionu, którą traktować można jako twór ukończony (lecz nie utwór: opublikowane przez Paula Valéry'ego Fragmenty Narcyza nie są szkicem, jest nim natomiast utwór Przeciwko Saint-Beuve'owi Marcela Prousta wydany przez Bernarda de Fallois). Szkic jest więc stanem, zazwyczaj częściowym, który pisarz uznał za ukończony (ale niezdatny do publikacji), a który czytelnik docenić może jako taki. Jest to już utwór, czy też tekst, lecz jeszcze nie dzieło².

Rękopis - stan pisma, na podstawie którego przygotowuje się tekst do druku. Praktycznie jest to ostateczny etap brulionów, moment, w którym twór ukończony staje się utworem.

Utwór - szczególny przypadek tekstu pisanego opublikowany pod czyimś (pisarza) nazwiskiem; wymiary nie mają znaczenia: książka, artykuł, samodzielny wiersz - liczy się tytuł i punkt końcowy.

Przekreślenie - rodzaj skreślenia, któremu towarzyszy, w formie nadpisku lub w dalszym ciągu tekstu, nowe sformułowanie (ewentualnie, po namyśle, bez innych modyfikacji - sformułowanie identyczne).

Redakcja - proces produkcji tekstu pisanego. Rozumiana z punktu widzenia fabrykacji, prowadzi do osiągnięcia kolejnych stanów (oraz/lub do stanu ostatecznego, czyli utworu). Rozumiana

\footnotetext{
${ }^{2}$ Rozróżnienie autora pomiędzy oeuvre i ouvrage, wyrazami bliskoznacznymi oznaczającymi „dzieło”, jest tutaj arbitralne, dostosowane do potrzeb terminologii, i niekoniecznie wynika z semantyki tych wyrazów. Literaturoznawcy francuscy stosują te pojęcia na ogół zamiennie, kierując się raczej względami stylistycznymi niż znaczeniowymi. Tłumacz proponuje dla œuvre odpowiednik „dzieło”, natomiast dla ouvrage - „utwór”, uwzględniając znaczenia nadawane tym pojęciom przez autora: w jego propozycjach „dzieło” jest instancją donioślejszą i zakresowo szerszą niż utwór. Istotnie, w języku francuskim wyraz œuvre może oznaczać „twórczość” danego artysty, a wyraz ouvrage odnosi się także do „aktu twórczego”. Wszelako już w niniejszych fragmentach sam autor nie jest konsekwentny w użyciu tych wyrazów, stąd pod hasłami "Szkic” i „Rękopis” pojawia się propozycja tłumacza: „twór ukończony” - w odróżnieniu od „utworu” oraz „dzieła”.
} 
z punktu widzenia swojego przebiegu w czasie odznacza się etapami, których rezultat może być ustanowiony lub nie (przepisany na czysto, przekopiowany) przez redaktora.

Wariant - szczególny przypadek modyfikacji, mogący wystąpić albo pomiędzy rękopisem a dziełem - w stadium próbek - albo też pomiędzy kolejnymi edycjami dzieła. Istnieje tendencja do kojarzenia wariantu z korektą w istocie jest to modyfikacja, która - niezależnie od swego pozornego znaczenia - transformuje całość tekstu; prowadzi ona do powstania - obok dzieła - innego dzieła (innego tekstu).

\section{Przybliżone założenia operacyjne}

Przed-tekst - całość, na którą składają się bruliony, rękopisy, próbki i „warianty”, rozumiane jako to, co materialnie poprzedza dzieło traktowane jako tekst, z którym może wspóttworzyć system. Wybór tego wyrazu, zbieżnego z „brulionem”, wynika z faktu, iż „brulion” konotuje charakter "odpadowy”, „nieuformowany”, „nieznaczący”. Konotacje te wprawiają w zakłopotanie, gdy stawką jest w istocie wyjście z problematyki perfekcyjności utworu literackiego obdarzonego (jedynym) sensem, jako skrywanym przez utwór sekretem. Byłaby to perfekcyjność przemieniona w utwór przez jakąś (niepojętą) wieczność, pochodząca albo z (boskiego) natchnienia, albo z (osobistej) medytacji wzniosłego (genialnego) ducha. Problem wynika $\mathrm{z}$ tego, że tekst nie jest punktem zwieńczenia, do którego zmierza redakcja, lecz momentem równowagi. Jeśli rozpatrywać wyłącznie mniejszy lub większy stopień niestabilności, gdzie i w jakim momencie zapada decyzja o uznaniu dzieła, które nie jest zwieńczeniem? Stąd zamysł terminu powiązanego ze znakiem „- tekstu” i przezeń określonego. Zakładamy zatem, że „przed-tekst” zawiera się w tekście (jest tekstem) i odwrotnie.

Pisanie - zdefiniowawszy redakcję jako modus oraz czas zorientowany na dzieło, pisanie rozumieć będziemy jako miejsce produkcji i produkcję miejsca, zwanego tekstem; to znaczy jako wprowadzenie serii obszarów znaczeniowych, konstytuowanych przez lekturę w trakcie ich przemierzania. Pisanie jest produkcją tekstu, lecz jedynie w takim sensie, że produkcja ta zawiera się w tekście, ten z kolei ją zakłada, z wyłączeniem rozważania rynku (przewidzianej publiki), potrzeb (autora zaangażowanego), estetyki (przyjętego kanonu). Metafora ekonomiczna, jaką implikuje termin „produkcja”, nastręcza pewnych niedogodności, które wymagają tu sprostowania. Produkt posłuszny jest imperatywom fabrykacji i wymogom komercyjnym; ponadto ulega zniszczeniu przez konsumpcję. Tymczasem tekst nie jest, jak produkt, odpowiedzią na te potrzeby. Na wzór tego, co nazywamy Bytem, tekst byłby raczej pytaniem. $Z$ tego powodu, jak i z innych, pisania nie można rygorystycznie powiązać z Podmiotem (jego poręczycielem ${ }^{3}$ ): pisanie jest skrzyżowaniem lub interwałem4. Skądinąd tekst nie podlega anulowaniu przez kon-

\footnotetext{
${ }^{3} \mathrm{~W}$ oryginale: répondant - to zarówno „poręczyciel” (w sensie prawnym), jak i osoba odpowiadająca (na pytania, na ankietę etc.); wyraz ma także konotację religijną: może oznaczać osobę, która odprawia mszę. Zarazem répondant jest formą imiesłowową od czasownika répondre - „odpowiadać” - i konotuje takie znaczenia, jak „zgodność”, „odpowiedniość”, „symetria”, „równoważność”.

${ }^{4} \mathrm{~W}$ tym miejscu w oryginale występuje gra słów wykorzystująca fakt, że dopełnienia w języku francuskim nie podlegają deklinacji: przez umieszczenie w kwadratowym nawiasie przyimka à, oznaczającego „w”, „na” lub „do”, przed wyrazami „skrzyżowanie” oraz „interwał” autor sugeruje, że pisanie nie tylko jest skrzyżowaniem oraz interwałem, lecz także może się w nich znajdować.
} 
sumpcję: lektura odtwarza to, co tekst ustanowił, tym samym lektura oraz pisanie ustanawiaja tekst, który natychmiast staje się monumentem (czyż nie mieści się w definicji pisania „zaklinanie czasu"? Pisanie różni się od mowy tym, że odmienia ono mowę do tego stopnia, iż odmieniona mowa staje się inną, pozostając tą samą). Monument jest dzieckiem tych, którzy go skonstruowali, lecz także tych, którzy biorą go pod rozwagę, nadają mu istnienie jako wspomnieniu, nadają mu sens. Należy jeszcze stwierdzić, że pisanie rodzi lekturę, która z kolei daje początek pisaniu w pełni tekstu, będącego zarazem zalążkiem i macierzą... Wzięte z osobna, metafory te nie są wystarczające - należy ukazywać je ciągiem, by wydobyć ich potencjał.

Lektura - operacja, w wyniku której z tekstu wyłania się sens wskutek przyjęcia pewnego podejścia, przy zastosowaniu określonych koncepcji oraz założeniu poziomu, na którym tekst ma być czytany (kontekst ideologiczny, wpływ społecznokulturowy, psychoanalityczne nieświadome, implicytna strukturalizacja wyobrażeń, wydźwięk retoryczny etc.). Czytelnik nie funkcjonuje tak jak odbiorca względem nadawcy, nie jest właściwym adresatem jakiejś wypowiedzi ${ }^{5}$, nie zajmuje się intencjami autora: jest współtwórcą tekstu, w tym sensie, że gromadzi on serię efektów sensu. Zamiast doszukiwać się zamiarów, tego, co chciano powiedzieć, czytelnik przemierza tekst śladami pewnej kongruencji, to znaczy wewnętrznej spójności, będącej zawsze w trakcie utwierdzania się. Kongruencja, którą odnajduje (wynajduje), nie ma nic wspólnego z logiką tak/ nie, czy $A=A \neq B$; ryzykując „niezgodność”, sytuuje się ona wyraźnie na każdym poziomie realizowania sensu, na którym występują poszczególne relacje składające się na system (przykład kardynalny stanowi Nieświadome). Powyższe zakłada, że tekst, w istocie i niejako z urzędu, jest polisemiczny. Lektura jawić się może jako zmyślanie lub koloryzowanie, jej prawda jest zawsze zmyślona, baśniowa, poza zasięgiem odgórnych założeń, jak „rozsądek” czy „estetyka”; jest ona inwestycją w całej rozciągłości pojęcia, i jako taka jest więc niepewna, przypadkowa. To za sprawą lektury potwierdza się swoistość, znamienność czynności pisania, stanowiącej dla niej grunt, za jej też sprawą utwierdzona jest wartość pola teoretycznego, w którym się sytuuje.

Dzieło - 1) ogół twórczości pisarza; gdy mowa o dziele Miłosza, chodzi o całość jego publikacji i wszystkie zapiski, jakie posiadamy. $Z$ tego tytułu dzieło włącza się w historię, zarazem przez chronologię publikacji, jak i momenty redagowania oraz datę, od której dzieło uznajemy (wszak dzieło odkrywa się stopniowo: fragmenty niepublikowane, korespondencje, etc.); 2) w ramach niniejszej pracy jest dzieło także synonimem tego, co rozumieć należy przez pojęcie „wiersz” (a co za tym idzie, także „powieść” czy „dramat”).

Wiersz - (La Charrette ${ }^{6}$ ) dany utwór, jako dzieło danego pisarza, opublikowany pod daną datą, włączony do danego zbioru - przynależący na liczne sposoby do świata literatury. W tym znaczeniu pismo istnieje jako zdeterminowane i ukończone ${ }^{7}$, przeznaczone dla jakiejś/konkretnej publiki, przedmiot studiów historycznych/historycznoliterackich (próbka, wzór gatunku „poezji” epoki „post-symbolizmu” czy też fin de siècle), dokument służący eksploracji danej kultury lub kultury w ogóle (egzemplarz wzorcowy danej „sztuki”, danego „stylu”, danej „mentalności)

\footnotetext{
${ }^{5} \mathrm{~W}$ oryginale wyrazy zapisane kursywą poprzedzone są odpowiednio rodzajnikami określonym i nieokreślonym, co sugerowałoby istnienie jednego (właściwego, „modelowego”) odbiorcy pewnej (jakiejś, „niezmiennej”) wypowiedzi.

${ }^{6}$ Zgodnie z objaśnieniami, dotyczącymi wieloznaczności tego tytułu, a także ze względu na funkcją niniejszego przekładu, wyłożoną w pierwszym przypisie do rozdziału „Bruliony”, tłumacz pozostawia oryginalny tytuł wiersza.

${ }^{7}$ W oryg. znowu gra słów: (dé)terminé: déterminer - „determinować”, terminer - „kończyć”.
} 
etc. Wiersz odróżnia się od tekstu w dwójnasób. Jako że został, przez swe „ukończenie”, wydzielony spośród brulionów, uznany być musi za doskonały, pełny, niemal uświęcony: ostateczny rezultat wysiłku świadomego i przemyślanego; czyni on pisarza „autorem”, odpowiedzialnym za swą produkcję, ręczącym za jej wartość. Stąd też domaga się wiersz, by czytano go - przynajmniej częściowo lub sumarycznie - „patrząc nań oczami” tego, który go skomponował. Ponadto, jako obiekt, wiersz stanowi część świata, włącza się do szerokiej sieci czasoprzestrzennej ożywianej przez prawa przyczynowo-skutkowe, posiada tożsamość i pozytywność. Ogółem, jeżeli tekst traktować można jako pochylający się nad sobą samym pomimo swej niestabilności, wiersz winien być badany jako zwarty i zamknięty. Jako punkt styczny wszystkich „kontekstów", wiersz może zostać wyjaśniony, za pomocą odniesień, natomiast tekst jest jedynie przedmiotem (lub podmiotem) lektur zakładających za każdym razem realizację jednego $\mathrm{z}$ ich systemów konstytutywnych; oto dlaczego mamy tendencję do uzgadniania, ujednolicania elementów jednego wyjaśnienia, podczas gdy pozostawiamy jako odrębne różne poziomy lektury.

Tekst - 1) względem przed-tekstu jest to tekst „definitywny” lub, dokładniej mówiąc, ostatni etap opracowania tekstu podpisany przez pisarza. Funkcjonuje jako kres - lecz nie jako cel - ciągu materialnych transformacji, kres wyznaczony (cięciem) ruchem pisania. $W$ istocie, będąc jeszcze zaledwie etapem przypadkowym, nie pozwala odrzucić przed-tekstu jako „nie-tekstu”; 2) względem dzieła lub wiersza jest to pismo jako materializacja, podpora i ognisko pisania oraz lektury, rozważane poza wszelkim odniesieniem do „podmiotu” wytwarzającego, do „podmiotu” konsumującego czy do warunków publikacji (zbiór, gatunek, Literatura jako całość). Z definicjii będzie tu tekst pismem, które pochyla się nad sobq samym ${ }^{9}$, miejscem spotkania dwóch operacji: pisania i czytania, które razem tekst ustanawiają. Jest to zespół znaków, które „odsyłają” wyłącznie do siebie samych oraz do swej organizacji hic et nunc. W przeciwieństwie do wiersza, będącego punktem odniesienia do kontekstów, tekst nie ma kontekstu $-\mathrm{z}$ wyjątkiem, być może, jego własnego przed-tekstu, o ile ten ostatni znajduje się dostatecznie poza nim, ażeby być z nim. Tekst nie jest przedmiotem umieszczonym tu raz na zawsze, obdarzonym konkretną celowością, zawierającym pewien sens, który by go całkowicie determinował: tekst byłby raczej momentem - nietrwałym, a także miejscem - prowizorycznym; albo też punktem strategicznym, którego wartość zależna jest od warunków jego zajmowania i którego współrzędne zmieniają się wraz z koniunkturą.

Myślenie o tekście - czy raczej: przemierzanie go, manipulowanie nim, wszak tekst jest nie do „pomyślenia” - wymaga odejścia od doktryny racjonalistycznej typu mechanicystyczno-pozytywistycznego w kierunku postawy fenomenologicznej i dialektycznej, zgodnie z którą tekst funkcjonuje jako praktyka, która nieustannie ustanawia się i przekształca, nie mając innego źródła ani innej egzystencji, jak tylko sam ów proces ustanawiania i przekształcania. Choć jest tekst miejscem ściśle ograniczonym, nie przeszkadza to w nieokreślonym przemierzaniu go. Powiedzieliśmy już, że nie istnieje on dla swego autora ani też dla jakiegoś „arcy-czytelnika”, jako dla podmiotów (psychologicznych): piszący oraz czytelnik są stanowiskami mieszczącymi się po dwóch stronach serii zamkniętych struktur. W rzeczywistości każdy czytelnik (re)aktywuje pewien model funkcjonowania na określonym poziomie.

\footnotetext{
${ }^{8}$ Wyraz „tekst" stosowany jest obecnie w specyficznych ujęciach - te przywołane tutaj nie konkurują ani też nie dążą do zniesienia pozostałych - przyp. aut.

${ }^{9}$ Wyrażenie se replier sur soi-même ma znaczenie figuratywne, odnoszące się do „pochylenia nad sobą" w akcie autorefleksji.
} 
N.B. Powyżej przedstawiono przybliżone pojęcia minimalne, jako że nie obejmują wszystkich możliwości, jakie oferuje przedmiot badań, a zarazem minimalistyczne, gdyż ograniczają się do eksplicytnych konkluzji istotnych dla steoretyzowania problemu. Zakładając, że sama problematyka ma zostać zrealizowana w ramach praktyki niepozostającej marginalną, wyłączną, ściśle speriodyzowaną (Miłosz/jeden wiersz/1915 - jakże skromna próbka!), wydaje się kwestią uczciwości zaproponowanie tych opcji. Pomimo ich orientacyjnego charakteru oraz eksperymentalnego zawężenia niektórym zdać się może, iż propozycje te mają wymiar ideologiczny: będziemy usatysfakcjonowani, jeżeli okażą się choć trochę operacyjne. Aparat pojęciowy wypracowuje się nie na bazie jednej próby, lecz drogą licznych analiz.

\section{Strukturyzacja formalna}

Zanim przystąpimy do próby opisania mechanizmów rządzących funkcjonowaniem form w powstającym wierszu, chcielibyśmy w kilku słowach wyłożyć, co wynika z poczynionych dotąd obserwacji. Wykażemy tym samym komplementarność takiej analizy.

Wiemy, jak niezręczna jest sytuacja, kiedy studiując dzieło literackie (ukończone), musimy - nie mogąc zarazem - rozdzielić to, co określono z dawna mianem „formy” i „treści”. Dążenie do prostego i klarownego zestawienia dwóch analiz byłoby, jak powszechnie wiadomo, zafałszowaniem rzeczywistości, w której nie do pomyślenia jest rozdzielenie tych dwóch poziomów: $\mathrm{z}$ jednej strony nie ma niesformułowanego znaczenia, z drugiej zaś - znaków zorganizowanych bez celu. Wydaje się, że taka sztuczna procedura wynikała z metod wykładni czysto dydaktycznej: jakże bowiem komentować jednocześnie ciąg idei oraz efekty wywoływane przez styl? Sukcesja okazuje się konieczna, nawet jeśli trzeba potem uzupełnić ten podział refleksją nad relacjami pomiędzy systemem treści a systemem ekspresji. Niezaprzeczalnie stosowanie tej praktyki przyczyniało się do wyobrażania sobie wewnątrz analizowanego zjawiska dwóch odrębnych rzeczywistości: znaczenia (mentalnego) oraz wypowiedzenia (operacji językowej rozpatrywanej pod kątem stylistycznym i estetycznym). Pomijając filozoficzne i ideologiczne implikacje takiego wyobrażenia, pomijając myśl dualistyczną, jaka przejawia się w tym sposobie postępowania (sens jest duszą, a tekst ciałem), pomijając nawet niebezpieczeństwo zniszczenia przedmiotu (co zostaje z wiersza, gdy się zeń wykroi prozę + muzykę?) - rozdzielenie formy i treści jest po prostu niewygodne.

W wypadku brulionów uznać można, że ta praktyczna trudność nie obciąża tak bardzo czytelnika. Jako że przed-tekst zawiera i pozwala odczytać historię kształtowania się tekstu, historia ta daje się łatwo prześledzić, jak widzieliśmy, jeśli traktuje się znaki jedynie od strony znaczonego, bez nadmiernej utraty swoistości badanego materiału. Na tyle, na ile wahanie pomiędzy takim czy innym sformułowaniem prowadzi do hipostazowania w formie wspólnego mianownika intencji znaczenia (motyw), badanie genetyczne wymaga operowania postaciami „resztek pojęciowych” - nawet jeśli dla ułatwienia określamy je poprzez ostatnie sformułowanie, jakie otrzymały, i nawet jeśli klasyfikacja konceptualizująca pozostaje operacyjnie problematyczna. Pozostaje otwarta możliwość rozpatrywania znaków od strony znaczonego (rozumianego w szerokim sensie, jako wszystko, na czym materialnie opiera się znaczenie): 
sprawdza się to zarówno dla osi paradygmatycznej leksyki, jak i dla osi paradygmatycznej dyskursu, przy czym nie można zapominać o wpływie czynników prozodycznych.

Nie znaczy to, że będziemy zajmować się formą dla uwydatnienia treści. Spróbujemy przede wszystkim zastanowić się nad działaniem form, nad sposobem, w jaki ujęcie w formę tworzy system, i nad sposobem, w jaki ta konstrukcja uczestniczy w formowaniu dzieła. Wszak to także prześwieca z przed-tekstu. Na wszystkich poziomach (słowa, zdania, strofy, brzmienia i rytmu) wybory formalne uczestniczą w postępującej organizacji tego, co sankcjonowane będzie przez tekst. Niewątpliwie rzeczą trudną będzie odróżnienie spontanicznego ruchu instancji formalnych w stronę spoistości zdolnej zapewnić ich stabilność a konsekwencjami tego ruchu dla działania treści ${ }^{10} \mathrm{w}$ ramach ich spójności. Obserwujemy „samorozmieszczanie” motywów oraz ich porządkowanie kosztem pewnych wykluczeń ${ }^{11}$. Skłania to do zaproponowania hipotezy, równolegle z konkluzjami poprzedniego rozdziału, że jeśli nasycenie wypowiedzi w przed-tekście wynika $\mathrm{z}$ fermentacji znaczonych, przymus form jawi się jako suwerenny w procesie usuwania niezgodności. Jakaś siła dośrodkowa kontroluje tu odśrodkowq wspaniałomyślność. Niemal nieograniczonej eksplozji wyrażalnego przeciwstawia się zdeterminowana implozja wypowiadalnego: sens wiersza wibruje w punkcie przecięcia tych dwóch przeciwstawnych dynamizmów.

W chwili, gdy pozostawiliśmy wiersz z takim układem motywów, jaki istnieje na końcu rękopisu, sytuacja przedstawiała się następująco: pięć części, których kolejność oznaczono cyframi rzymskimi: I: strofy I, II i III (motywy ABCDEFG)II: strofy IV i $V$ (motywy HJK)

III: strofy VI i VII (motywy LMNO)

IV: strofy VIII, IX i $X$ (motywy $P Q R$ )

V: strofy XI, XII, XIII i XIV (motywy STUVWXYZ)

Podział ten obejmuje - z wyjątkiem A I - warstwy redakcji oraz ukazanych nagromadzeń semantycznych.

Otóż od pierwszej publikacji w zbiorze Adramandoni (podobnie jak w wypadku wznowienia wiersza cztery lata później, w roku 1922, w zbiorze Wyznanie Lémuela) są już tylko cztery części, również oznaczone cyframi rzymskimi: część I nie ulega zmianom, II i III stają się II, IV staje się III, zaś V staje się IV. Można by myśleć, że takie podziały były dziełem przypadku, kwestią maniery lub kaprysu: za dowód niekonsekwencji Miłosza można by przyjąć fakt, iż zniósł wszelki podział oraz numerację w ostatnich edycjach, których doglądał: Wiersze 1895-1927 wydane w roku 1929 przez Fourcade, a także Siedemnaście wierszy Miłosza wydane przez Editions Mirage w 1937.

Uważamy jednakże, iż podział na cztery części jest bardzo znamienny. W roku 1918, w momencie wydania tego wiersza, którego rękopis gotowy był już od roku 1917, poeta zdaje się odkrywać tę czteroczęściową konstrukcję zapisaną niejako w samym wierszu. Musiała mu się ona

\footnotetext{
${ }^{10} \mathrm{Tu}$ w liczbie mnogiej.

${ }^{11}$ Trudno powiedzieć, czy „samorozmieszczanie” oraz „porządkowanie” motywów mają charakter zwrotny. Tłumacz zdecydował się na niewprowadzanie zaimka „się”, którego brak w oryginale budzi przeczucie widma Autora (Poety), majaczącego na horyzoncie rozważań. Jest to pewien paradoks, ponieważ w dalszej części paragrafu „przymus form” otrzymuje status „suwerena”, co znowu czyni poetę swego rodzaju mediatorem, inżynierem, skrępowanym prawami spoistości (jako zdolności do tworzenia połączeń) i spójności (jako właściwości systemu połączeń). Podobnie wypowiedź tłumacza, oparta siłą rzeczy (przymusem form) na poetyce stosowanej przez autora, zaczyna niepokojąco przypominać wypowiedzi konstruowane przez samego Noela.
} 
wydać oczywistą od chwili (re)lektury La Charrette jako ukończonego wiersza (a nie jako harmonijnego pogodzenia wielu nieudanych prób?), jako wiersza obcego. Wyobrażamy sobie, że pod koniec redakcji pisarz zmuszony był zachować podział (na pięć części), który wpisany był w samą genezę jego dzieła: presja treści oddziaływała bardzo silnie, same treści cechowało bogactwo emocjonalnej inwestycji. Po kilku miesiącach przerwy, odnawiając swój kontakt $z$ wierszem, pisarz odkrył rzeczywistość podziału czteroczęściowego, pozostając zarazem wrażliwym na spoistość eksplicytnej organizacji: zmienił numerację. Dziesięć lat później ten podział okaże mu się zbyteczny: struktura tak utwierdzona może się obejść bez dodatkowych oznaczeń.

W tekście wszak widoczne są cztery części, nawet jeśli nie podkreślają tego żadne oznaczenia. Oczywiście, podczas pierwszej lektury dominuje wrażenie melancholijnej płynności, sztuki przez swą elastyczność nieco verlaine'owskiej, miękkości konturów i melodii. Odnosi się wrażenie, że nie ma w La Charrette dostrzegalnej architektury. Brak stałego rytmu w wersach, niewielka autonomia strof, plątanina tematów powracających niby przypadkiem: wszystko zmierza do zatarcia szwów, sprawiając wrażenie, że strumień jest nieprzerwany, całością rządzi ciągliwa plastyczność, niezróżnicowanie formy, tłumaczące niepokój i dezorientację właściwą przebudzeniu... Pisarstwo Miłosza prezentuje się zasadniczo pod znakiem płynności; postępuje warstwami lub falami, przez ciągłe modulacje; lubi progresję sukcesywnych przesunięć, ale bez przerw i bez szczelin; sprzeciwia się granicom wyraźnie zaznaczonym, wszelkiemu zdecydowaniu; wymyka się określeniu w każdym swym aspekcie, i nawet regularność taka jak ta zakłada swobodne równomierności. Nie zmierza wszelako do rygorystycznego spłaszczenia, które - całkowicie uniformizując dyskurs i głos - odtwarzałoby z kolei, na swój sposób, pewien rodzaj masywności niezbyt sprzyjającej imitacji. Wszak tym, do czego dąży Miłosz ostentacyjnie zarówno w swej praktyce poetyckiej, jak i w refleksji teoretycznej, jest tajemnica analogii, innymi słowy, mechanizm fuzji między niskim i wzniosłym, nieustanne ślizganie się pomiędzy tutaj i tam, rozwiązanie przeciwieństw... Takie nastawienie zakłada zawsze pozostawienie otwarcia, drogi ucieczki ku nieskończoności. Otóż równina doskonale płaska, która usypia, izoluje dokładnie tak samo i zamyka w sobie jak górzysty krąg, który przygniata: jedynie przemienność różnic i powtórzeń, którą uwydatnia pejzaż umiarkowanie przypadkowy, daje zasmakować w odnawiających się horyzontach i fascynacji tajemnicą.

I już pogrupowanie strof zawiera tę skromną wariację: $3+4+3+4$; żadnego bezwzględnego odstępu, żadnej monotonii. Dwumiany są do siebie podobne, jednak sąsiadujące grupy są nierówne. Fakt tej pierwszej nierówności (3 / 4) pozwala domyślać się, że równomierność dwóch części wiersza $(3+4 / 3+4)$ nie jest równaniem tożsamości. Wznowienie nie może być po prostu reedycją, odznacza się jako nadejście czegoś innego.

Czteroczęściowy podział wiersza postrzegać można jako dyskretną strukturę, lecz nie jako system narzucający się (tyraniczny i imponujący). Są więc cztery grupy strof, każda charakteryzuje się obecnością potrójnej całości ostatniego wersu ostatniej strofy. I tak: w wersie 12: krzyk, krzyk, krzyk $k^{12}$; w 28: smutny, smutny, smutny; w 40: trzy przedmioty na stole: Biblia, Faust, chleb; w 56: już nie mogę, nie, już

\footnotetext{
${ }^{12}$ Tłumaczenie doraźne: podobnie jak w pozostałych fragmentach tłumacz koncentruje się bardziej na zobrazowaniu omawianego przez autora zjawiska niż na poetyckim wymiarze wiersza.
} 
nie mogę, już nie mogę. Trzecia grupa różni się od innych: wieńczą ją trzy powiązane ${ }^{13}$ ze sobą znaki, nie zaś potrojenie jednego znaku. Z drugiej strony, grupy I, II i IV łaczy obecność słowa „życie ${ }^{\text {"14 }} \mathrm{w}$ każdej strofie początkowej oraz końcowej (wersy $3+9$ / 13 + 25 / 42 + 53); w grupie III słowo to nie występuje, lecz było ono nieustannie powiązane z dominantą wokalną /i/: l'esprit purifié, bruit hivernal de la vie + crie, a dalej vie orpheline ... o vie si longue... ville + tristes ${ }^{15}$. Okazuje się, że strofy początkowa oraz końcowa III grupy zawierają tę samą dominantę fonetyczną: Te voici donc, ami d'enfance! Premier hennissement si pur, si clair... pluie! jadis-Ulysse-îles-archipels-Bible ${ }^{16}$ (do czego dołącza się także graficzna, wizualna obecność trzech /i/ w ostatnim hemistychu: apparait/pain/matin). Choć ukryta, ich ekwiwalencja jednak istnieje. Gra podstawień nabiera sensu: konieczne było powtórzenie oznaczeń (/i/ - vie - x3), ażeby istniał system; wznowienie musi być osłabione, by pokazać, że to wciąż jeszcze ta sama rzecz, ale już inna: zaczyna się inaczej. Powrót tych oznaczeń w grupie IV podkreśli echo, z tą drobną różnicą, że potrójne fonemy mają nową wokaliczność (peux plus ${ }^{17}$ ) względem poprzednich (/i/), odchodząc od formuły trzech znaków (Bible-Faust-pain) na rzecz starej formuły potrójnego znaku ${ }^{18}$.

$[\ldots]$

Również sposób, w jaki strofy są z sobą powiązane, zasługuje na wnikliwy ogląd. Pierwsza przerzutnia, między strofami IV i V nie zakłóca biegu długiej frazy (której zwieńczenie odwleka się za sprawą rykoszetów przyłączanych rzeczowników): Ces fleurages, comme on les voit dans les faubourgs/ Aux tentures des mures en démolition sous la pluie, wers 17 niejako naturalnie przedłuża wers 16. Efekt ten ukazuje się wyraźniej pomiędzy strofami VI i VII: ...; et voilà,// O vie si longue, pourquoi mon âme...; nie tylko wers 24 kończy się anaforycznym voilà, którego użycie należałoby ściśle powiązać z tym, co zapowiada. Jednak wstawiony segment zdania jest apostrofą, która akcentuje odstęp, wszak wychodzimy tu w pewnym sensie od sieci znaczeniowej ustanowionej przez główne zdanie. Przeczuwamy więc ambiwalencję zabiegu, który jednocześnie wzmacnia i znosi odstępy między strofami. Nie ma zerwania, jest zawieszenie: syntaktyczne - przez ucięcie eksklamacji, rytmiczne - za sprawą przerzutni ze strofy na strofę. Analogiczny mechanizm, jakkolwiek odwrócony, zapewnia - i zakłóca - przejście między strofami VIII i IX: J'entends aussi... mon frère;/ Les outils sur l'épaule et le pain sous les bras,// C'est lui!...19, które podkreśla lub zwieńcza w afektowanym rejestrze ten ruch, który nazwać

\footnotetext{
${ }^{13}$ "Chleb" pomiędzy dwiema księgami oznacza pojawienie się w tym punkcie wiersza potrzeby strawy materialnej obok strawy duchowej. Zestawienie to nie jest oczywiście bez znaczenia: nadaje się kształt życiu dzięki lekturom „ożywczym” (księga o początkach i księga o powrocie do źródeł). Duszę należy karmić, dzieląc chleb z Pośredniczką... Dla Miłosza kontaminacja tego, co fizyczne i mentalne, jest jeszcze dookreślona na poziomie symbolicznym: Swedenborg nauczał, że chleb odpowiada na ziemi słowom prawdy w świecie anielskim (por. analogiczna symbolika występująca w misteriach eleuzyjskich) - przyp. aut.

${ }^{14}$ Dowód a contrario tego mechanizmu: wers 21 przez długi czas zaczynał się - ze względów rytmicznych, eufonicznych? - od słów „o, życie!”; dopiero w ostatnich przeróbkach zaczynać się będzie od „Cóż czynić? Uciekać?...”. Wyraz „życie” był tu nadmiarem - przyp. aut.

${ }^{15}$ Instrumentacja głoskowa wokół samogłoski „”; w wolnym tłumaczeniu: „duch oczyszczony, zimowy hałas życia + krzyk, życie sieroce, życie tak długie... miasto + smutne [1. mn.]".

${ }^{16}$ Kolejna instrumentacja: „Ty oto, przyjacielu z dzieciństwa! Pierwsze rżenie, tak czyste, przejrzyste... deszcze/ niegdyś-Odys-wyspy-archipelagi-Biblia".

${ }^{17}$ „[Nie] mogę już”.

${ }^{18} \mathrm{Da}$ się nawet wykazać wtórne wariacje w trzech potrojeniach tego samego słowa, wariacje zarazem rytmu i brzmienia: crie, crie et crie / tristes, tristes, tristes (poziom zero) / je ne peux plus, non, je ne peux plus, je ne peux plus. Wtrącenia działają w kierunku odwrotnym: pierwsze (et) znajduje się pomiędzy elementami 2 oraz 3 , trzecie między 1 i 2; pierwsze łagodzi (nadaje giętkości), trzecie mocno podkreśla - przyp. aut.

${ }^{19}$ „Słyszę też... mojego brata;/ Narzędzia na ramieniu i chleb pod pachą,/ To on!...”.
} 
można opisowym. Między strofami IX a X powracamy do formuły łagodnych powiązań: ... et le cour se déchire/ Quand sur la table étroite... ${ }^{20}$, która powtarza się między strofami XI i XII (avec de belles saintes mains// Doucement descendues) ${ }^{21}$ i między XII a XIII (les épaules et les genoux// De la pieuse tiraient l'étoffe de la robe...) ${ }^{22}$; zawieszenie jest tymczasem coraz bardziej widoczne wewnątrz tej serii: pomiędzy rzeczownikiem i określającą go syntagmą, a także między rzeczownikiem a określającym go przymiotnikiem. Wszelako punkt kulminacyjny osiągnięty zostaje, jak można się było spodziewać, w ostatnim połączeniu między strofami: XIII zamyka inwokacyjne ô, XIV zaś zaczyna się inwokowanym rzeczownikiem „Życie!”. Śmiałości w tej sferze da się posunąć dalej, z wyjątkiem może podzielenia wyrazu na sylaby rozmieszczone w dwóch wersach, jak czynią powszechnie niektórzy konkurenci Apollinaire’a.

Wobec podobnej sytuacji należy zastanowić się, jeśli nie nad zasadnością samej koncepcji „strofy”, przynajmniej nad znaczeniem powrotu $w$ tym przypadku do formy stroficznej. Najbardziej zadowalająca hipoteza brzmi następująco: forma stroficzna zaburzona od wewnątrz przez własne zaprzeczenie służy jednocześnie odmianie ${ }^{23}$ regularności (formy zamknięte) oraz nieregularności (struktury otwarte). Jeden rzut oka na całość twórczości Miłosza ujawnia skłonność poety do tego amalgamatu czy też hybrydy; można by wykazać, iż wysiłek godzenia ciągłości i nieciągłości, jakości i ilości, ograniczoności i nieograniczoności - a raczej wysiłek przekraczania lub przemieszczania tych opozycji - znajduje się w centrum poszukiwań Miłosza w sztuce, w „nauce” i w Metafizyce. Niech wystarczy tu odnotowanie zjawiska, które zaobserwujemy także na poziomie wersów. Wszystko odbywa się tak, jak gdyby potrzeba było zarazem geometrycznych brył oraz pewnej płynności. Bruliony dowodzą, że podobne przerzutnie były bardzo wcześnie dopracowane, nienaruszalne. Ponadto strofy, pomiędzy którymi występują, od początku projektowane były razem, stanowiły całość.

Takie rozmieszczenie grup strof, mocniej lub słabiej sczepionych, zapewnia w konsekwencji maksymalną stabilność wiersza. Rządzące nim ekstremalne napięcie amplifikuje echa i odgłosy między odmiennymi momentami dyskursu. Umożliwia to kompensację utraty sensu związanej z linearnością i sukcesywnością języka. Poezja nabiera kosztem tego autonomii, która nie jest jej pomniejszą właściwością; opiera się czasowemu rozlewaniu przez równoważność przestrzennego rozszerzenia, mobilizuje czas przeciwko czasowi, sytuuje się w chwili, jako stałość i kruchość zarazem.

Żałując, iż wymogi prezentacji choć trochę systematycznej wymagają sukcesywnego studium różnych planów, na których odbywa się wypowiedź poetycka, wyróżnimy jeszcze dwa plany tej analizy działania języka: jeden, który określić możemy jako „gramatyczny”, obejmuje zjawiska związane z leksyką i składnią, drugi zaś, „prozodyczny”, obejmuje efekty uzyskane przez organizację rytmiczną i dźwiękową. To czyniąc, oddalamy się coraz bardziej od tego, co wynika w dyskursie z doświadczenia (bazowego), by skierować się ku przestrzeni znaków i, ostatecznie, znaczących. Nie znaczy to, by istniała między tymi planami jakaś hierarchia: musimy je

\footnotetext{
${ }^{20}{ }^{2} . .$. i serce się rozdziera/ Gdy na wąskim stole...”.

${ }^{21}$ „Pięknymi, świętymi dłońmi/ Co łagodnie zstępują”.

${ }^{22}$ „Ramiona i kolana/ Obleczone tkaniną sukni”.

${ }^{23} \mathrm{~W}$ oryg. conjuguer - koniugować, ale także łączyć.
} 
brać z osobna, mówiąc o nich językiem niezbyt dobrze dostosowanym. Z całą pewnością układ dużych całości ( $w$ tym wypadku równych lub większych od strofy) winien być traktowany w kategoriach semantycznych, tymczasem sieć wartości dźwiękowych (czy też „graficznych”) niezbyt się temu poddaje. Nie zmienia to faktu, że w wierszu wszystko ma sens - i wszystko ma sens jednocześnie.

\section{Opracowanie lingwistyczne}

Rozumiemy przez przymiotnik „lingwistyczny” ogół procesów, na których tradycyjnie skupiają uwagę lingwiści. Co się tyczy terminu „opracowanie”, oznacza on fakt pisania, którego opis pokrótce przypomnimy. Miłosz stara się od razu produkować „wersy”. Przekreślenia, które chciałoby się uznać za „przekreślenia dla ucha” (właściwy rytm, odpowiednie brzmienie), następują od pierwszego rzutu. Nie można powiedzieć, że segment tekstu objawia się w pełni uformowany ani też - przeciwnie - że zarysy myśli pojawiają się na kartce, by zostać następnie wzbogaconymi i upiększonymi. Brak tutaj także, jak ma to miejsce w wypadku Valéry'ego, ustanawiania "palet” słów (homonimów lub synonimów), z których można czerpać materiał na wersy. Bruliony Miłosza sprawiają najczęściej wrażenie bełkotu.

Oto przykład typowy. W momencie, w którym poeta decyduje się podążać za ruchem zapoczątkowanym przez pełne rozczarowania stwierdzenie „To jak słowo, które padając na papier traci swój sens", odnotowujemy następujące wahania (każda linia jest w istocie przekreślona, by pozostawić miejsce kolejnej):

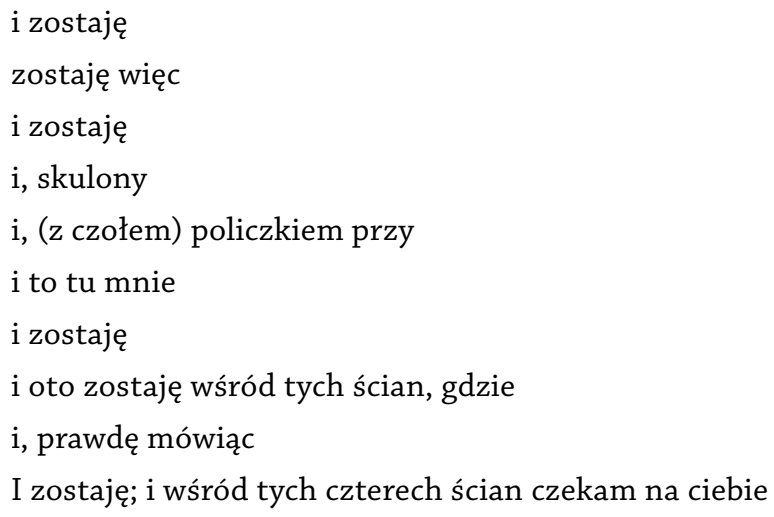

Ciąg dalszy ma niewielkie znaczenie ${ }^{24}$. Uderzająca jest natomiast niemożność rozpoczęcia, a także niewiedza, co będzie dalej. Kiedy pojawi się formuła „dusza przebita”, ustanowione zostanie so-

\footnotetext{
${ }^{24} \mathrm{~A}$ jednak, nie mogąc sformułować wcześniejszego fragmentu, Miłosz zatrzymuje się tu 10 marca 1916 roku, zawieszenie trwać będzie do 16 marca, kiedy poeta rozwinie: „...traci swój sens. (Oto jak, Królu Salemu, zaczyna się i kończy mój dzień) Oto, Królu Salemu, mój piękny królu pokoju, dusza ma jest przebita"; lecz otrzymuje tym samym strofę pięciowersową. 22 marca zmieni się to w „...caty swój sens. Oto/ Me życie, oto całe życie, że aż biedna dusza jest przebita/ Kiedy” (etc.). Wszystko, czemu dawało początek owo „I zostaję”, przeszło $\mathrm{w}$ „I oto”. To, co uważny komentarz mógłby zrekonstruować, ryzykując arbitralność, znajduje potwierdzenie w badaniu brulionów. „I oto” oznacza zatem coś jak: „I oto znów ja, zamknięty w kręgu mej izby, w kieracie mej bezczynności, spragniony opieki, przesycony nudą, niezdolny uciec ku Dali, która mnie fascynuje...”. Stąd „przebita dusza” implikuje nie tylko rozdarcie, lecz także unieruchomienie, fiksację, przebicie - raczej przyszpilonego motyla niż krwawiącą ranę; zza tego profilu wyłania się zaś Ukrzyżowanie.
} 
lidne ogniwo i trzeba będzie wypełnić pustkę pomiędzy zdaniem „traci sens” a tą nową pozycją. Musimy z góry uznać, że z jednej strony owo nuklearne ogniwo jest do wymyślenia (w sensie: do obnażenia; było tam już w „męczeńskiej” sytuacji człowieka w chwili przebudzenia), z drugiej zaś - że trzeba je następnie zintegrować. Ogólnie biorąc, bełkot polega albo na tym, „co powiedzieć?”, albo na tym, ,jak powiązać?”, albo na obu tych kwestiach naraz.

W konsekwencji mechanizm opracowania okazuje się działać w dwóch momentach. Pierwszy moment polega na fabrykacji dużych całości: wszystko wskazuje na to, że poeta nie może się powstrzymać od strukturyzowania dużych całości (strof lub grup strof), by sprostać wymogowi spoistości, bez której nie może kontynuować. Drugi polega na aranżacji wszystkich elementów należących do wiersza jako całości (nie do samego wiersza ostatecznego, ale do wszystkich „wierszy prowizorycznych”, które cytowaliśmy na poszczególnych etapach. Powiedzielibyśmy, że opracowanie działa najpierw jako umieszczenie, następnie zaś jako dopracowanie.

$[\ldots]$

\section{Od przed-tekstu do tekstu}

Jaką lekcję wyciągnąć z takiej eksploracji? Jak wyobrazić sobie kształtowanie się wiersza jako całości? Przede wszystkim zaś, jak badać, by użyć uświęconego terminu, „genezę” stanu zwieńczenia pośród gmatwaniny jego stanów prowizorycznych?

Kto mówi o genezie, odwołuje się do pewnego rodzaju kreacji: wychodząc z niczego lub też, dokładniej mówiąc, z punktu zero. Oto jak wersy następują po sobie i łączą się. Z racji teraz już oczywistych postawimy problem w kategoriach transformacji. Bruliony La Charrette (całe dossier, ma się rozumieć) liczą około 1500 zapisanych linijek dla około 150 wersów „przedstawialnych", wreszcie zaś jakieś 50 wersów stanowiących tekst. Jest to więc narastanie, wszak setki słów zostały zmobilizowane przy okazji tej redakcji, wokół intencji pisania (co nie znaczy wcale: „treść już pomyślana”), setki słów starannie naniesionych do zeszytu będącego dla pisarza miejscem ćwiczeń, czy też terenem manewrów. Lecz jest to zarazem dopasowywanie: poza opracowaniem detali (które z ilościowego punktu widzenia oceniać można jako redukcję do dziesiątej części) doszło do selekcji i kombinacji 56 wersów spośród 150 zdań obdarzonych formą i sensem. Są to dwie operacje zorientowane w przeciwnym kierunku, przeprowadzane równolegle, choć w sposób nieciągły - etapami, tak, jak to zostało pokazane.

Jest rzeczą delikatną wyobrazić sobie te operacje współdziałające w procesie fabrykacji, a nawet nadać im nazwę. Zdecydowaliśmy się określać je jako narastanie i dopasowywanie ze względu na mglisty charakter obu tych słów. Użycie takich pojęć, jak zwiększanie i zmniejszanie, kładłoby istotnie zbyt duży nacisk na intencję pomnażania i redukcji całkowitej liczby wersów, podług jakiejś nieznanej normy. $Z$ kolei ekspansja i kondensacja pozwalałyby przypuszczać, że ilość substancji pozostaje niezmienna, ale w różnych stopniach istnienia i nasilenia. To, że się wiersza poszukuje, nie oznacza wcale, że odkrywa się go koniecznie a priori większym lub mniejszym, swojskim czy 
zjadliwym. Wymiary oraz gęstość stanowią integralną część tekstu. Podobnie unikamy mówienia o „płodzeniu” wiersza; sugerowałoby to - na wzór zjawisk biologicznych - dokonywanie się pewnej proliferacji słów-komórek, jednych z drugich, w taki sposób, że następne byłyby córkami poprzednich. Nie może też być mowy o „kiełkowaniu” brulionu - rozwoju z jednego zarodka, umieszczonego w odpowiednich do dojrzewania warunkach, gdzie pod postacią programu zawierałyby się wszystkie jego przyszłe pędy. Nie możemy uciec od języka metaforycznego, jest mimo wszystko rzeczą pożądaną unikanie rejestru czerpiącego z biologii ewolucyjnej (zwierzęcej czy roślinnej), noszącej w sobie zarodek witalizmu, mogący przeobrazić się w niebezpieczne złudzenie.

Zagadnienie produkcji tekstów domagałoby się opisu korzystającego z obrazowania zapożyczonego od krystalografii - lub przynajmniej by go dopuszczało. Podobnie jak komórki zgromadzone jednostki sensu łączą się zgodnie z prawami danego systemu. W fizyce system ten związany jest z liczbą i położeniem „punktów połączeń” rozmieszczonych, by tak rzec, na powierzchni komórek. Połączenie dokonuje się w wyspecjalizowanych formacjach dążących do nasycenia w celu utrzymania równowagi ze środowiskiem zewnętrznym. Sieć krystaliczna zachowuje się tak, jakby sama nadawała sobie własne komponenty i formy najbardziej efektywne, zależnie od temperatury, ciśnienia etc. Kryształ organizuje to, co już-tutaj, w nową - jakkolwiek spodziewaną - konfigurację o nowych właściwościach, optymalnych względem koniecznego oporu. Jego stabilność pozostaje wszelako niepewna z powodu licznych uwarunkowań, jakim podlega. Krystalizacja polega jednocześnie na gromadzeniu i generacji, nie sprowadza się ani do jednego, ani do drugiego zjawiska.

To, co ochrzciliśmy (po fakcie) mianem przed-tekstu, jest cieczą, środowiskiem koloidalnym, w którym jednostki języka poszukują i odnajdują swe połączenia najkorzystniejsze dla procesu krzepnięcia. Maksymalna trwałość zostaje osiągnięta, kiedy sieć jest w pełni nasycona. Nasycenie dokonuje się jednocześnie na dwóch planach, semantycznym i formalnym (ten ostatni dzieli się tu na syntaktyczny i prozodyczny).

$[\ldots]$

\section{Konkluzja: w stronę poetyki brulionów?}

Zstępując z tego olimpu, na który trafia nieraz krytyk pod wpływem uniesienia, w radości zdobywania dziewiczych szczytów, pośród rozpadlin, w których przez nieuwagę najpiękniejsze przedsięwzięcia czekać może zguba, powracając z tych upojeń, których złudę niezastąpioną i bogactwo beznadziejnie wątpliwe opiewał Zaratustra, trzeba na nowo wkroczyć w rzeczywistość, wyzwolić się z uniesień, z sieci konstelacji, by zamknąć się w rygorystycznym rozrachunku.

Po co jednak powtarzać trasę już przemierzoną? Moglibyśmy jedynie dokonać innego studium, wypaczonego lub zafałszowanego - nie należy więcej o tym mówić. Lepiej patrzeć naprzód, w stronę przed-tekstu. Stwierdzić, na przykład, że opracowanie krytyczne tekstów powinno w sposób rozmyślny i systematyczny zajmować się przed-tekstami albo że należy ustanawiać, upowszechniać i teoretyzować „poetykę brulionów”. Pod rygorem skazania na lekturę okaleczoną - i okaleczającą. 
Podstawowy cel, gdy już ustali się istnienie i dokona transkrypcji zarysów lub bezpośrednich szkiców dzieła, polegać będzie na ustanowieniu tekstu oraz przed-tekstu: na zestawieniu ich ze sobą. Nie po to, by oprzeć je na podstawce do książek, tylko po to, by je ze sobą zmieszać. Nie po to, by uśpić piękny wzorzec w spokoju jego początków, lecz by zbudzić go z tego rodzaju dogmatyzmu, do którego prowadzi pewność rodowodu. Nie po to, by go zabalsamować, lecz by go pokroić. Zakłócić jego spokój.

Musi być możliwe uczynienie z każdego szczęśliwie odnalezionego przed-tekstu - prawdziwego tekstu. Wszak odwrotnie przecież transformuje się powszechnie teksty w ich własne przed-teksty, starając się rozszyfrować sekrety ich powstawania. Musi być możliwe nie tyle sprawić, aby przed-tekst ukazał duszę tekstu - wszak jest tu ona bardziej niż gdzie indziej jego „przyszłym oparem” - ile oddać tekstowi jego należność, która go ustanawia. Uznać i ogłosić ową zręczną sztukę, która przemienia tekst w obiekt uświęcony, porzucony na pastwę aparatów krytycznych (lub krytyków aparatów?), złożony w ofierze nieświadomości poniżenia, pozostawiony upodobaniom maskującym pogardę. Gdzież bowiem sytuuje się przepaść między przed-tekstem, biednym krewnym, a tekstem, kuzynem z Ameryki? Dlaczego nie odwiedzają się nawzajem, mają wszak wspólny rodowód, wywodzą się z tej samej linii, w tym samym zmierzają kierunku.

A zatem stosować wobec przed-tekstu te same zabiegi, które narzucano tekstowi i które dotychczas dla niego były zarezerwowane, bez przywileju i bez dyspensy. Najpierw z osobna, zgodnie ze stawianym pytaniem; następnie zaś konfrontując ze sobą tekst i przed-tekst - w takim śledztwie wszystko może wyjść na jaw: kłamstwa, fałszerstwa, sprostowania, wzmocnione twierdzenia, ukryte skarby. Chciałoby się zapytać lingwistów, dlaczego nie pochylają się nad bełkotem, nad nieudolną frazą u osób niedotkniętych afazją. Chciałoby się powiedzieć styliście, by zajął się niepowodzeniami, impasami, mieliznami stylu. Dla każdego jego obol.

Niemniej wymyślać specjalny sposób badania brulionów oznaczałoby popełnić dziwaczną, symetryczną pomyłkę. Akt badania jest jeszcze podporządkowany, jak się zdaje, założeniom teoretycznym (ci z wysokich kast mają wygórowane poczucie nietykalności). Sposób musi być taki sam - dla tych samych pożytków, $\mathrm{z}$ analogicznym ryzykiem, jakkolwiek z pewnością zmniejszonym, wszak widzimy wyraźniej w bałaganie, bełkot bywa często bardziej precyzyjny niż wymuskana fraza.

Nie należy dążyć do specjalizacji w „brulionomanii”. Należy raczej poszerzyć krąg badań literackich o wszystko, czemu przyznać można status tekstu, począwszy od prawie-tekstów, takich jak utwory należące do literatur zwanych „marginalnymi” (ustne, ludowe) - co już się dzieje - poprzez przed-teksty, gdziekolwiek je znajdujemy i jakikolwiek tekst poprzedzają. Ostatecznie nie chodzi więc o poetykę brulionów: chodzi o poetykę aż po bruliony! 


\title{
SŁOWA KLUCZOWE:
}

\author{
krytyka genetyczna
}

JEAN BELLEMIN-NOËL

\section{przed-tekst}

\begin{abstract}
Abstrakt:
W niniejszej publikacji prezentujemy fragmenty książki Jeana Bellemin-Noëla zatytułowanej Tekst i przed-tekst, bruliony wiersza Oskara Miłosza z roku 1971, jednej z pozycji założycielskich zrodzonej we Francji praktyki badawczej znanej jako krytyka genetyczna tekstu. Praca Bellemin-Noëla stanowi prekursorską próbę metodycznego ujęcia literackiego procesu twórczego na podstawie analizy zachowanych rękopisów, notatek i szkiców poety. Zgromadzony korpus tekstów, nazywany „brulionami”, poddany został klasyfikacji i opisowi, następnie zaś sekwencji odczytań służących rekonstrukcji kolejnych etapów powstawania utworu. Badacz zwraca uwagę na czysto „techniczne” aspekty korpusu będące świadectwem zmian zachodzących w kolejnych redakcjach wiersza. Zmiany i korekty kompozycyjne, składniowe, leksykalne, a także skreślenia czy dopiski - świadczyć mają o procesie myślowym kryjącym się za aktem twórczym, będącym - jak podaje Zofia Mitosek - procesem nie tyle przekazywania, ile tworzenia znaczeń.
\end{abstract}


metodologia badań literackich

\section{OSKAR MIŁOSZ}

\section{NOTA O AUTORZE:}

Jean Bellemin-Noël (ur. 1931) - wykładowca (1969-1975), następnie profesor (1976-1992) literatury nowożytnej i współczesnej na Uniwersytecie Paris VIII Vincennes (obecnie Paris 8 Saint-Denis), doktor filozofii (1955); założyciel i dyrektor kolekcji „Le texte rêve” w PUF (1990-1996). 